\title{
Pemberdayaan Remaja Melalui Kajian Milenial (KAMI) di Kampung Cigintung Desa Legokhuni
}

\author{
Rina Nurmala \\ Program studi Komunikasi \& Penyiaran Islam, STAI DR. KH. EZ. Muttaqien Purwakarta \\ e-mail: nurmalarina16@gmail.com
}

DOI: https://doi.org/10.52593/svs.01.1.02 Naskah diterima: 19 Desember 2020, direvisi: 22 Desember 2020, disetujui: 11 Januari 2021

\begin{tabular}{ll}
\hline Abstraksi & Kegiatan pengabdian ini dilatarbelakangi dari munculnya \\
\hline Kata Kunci: & perubahan mental remaja di legok huni dengan ditandai \\
Pemberdayaan, & munculnya perubahan fisik, sosial, emosional di aspek interaksi \\
& sosial masyarakatnya, sehingga menggerus nilai-nilai spiritualitas \\
& yang ada dala pribadi remaja tersebut. Berdasarkan hal tersebut, \\
& kegiatan ini bertujuan untuk memberikan sosialisasi dalam \\
& menumbuhkan wawasan dan kesadaran guna mempertahankan \\
& diri dari perilaku menyimpang dengan membentuk suatu forum \\
& remaja yang disbut KAMI. Hasil dari kegiatan ini diperoleh bahwa \\
& KAMI sebagai sebuah wadah ataupun ruang bagi remaja untuk \\
& mendapat pembinaan agama, dan pelatihan-pelatihan yang dapat \\
& meningkatkan keterampilan mereka sangat dibutuhkan oleh \\
& mereka guna meningkatkan kualitas sumber daya manusia baik \\
& secara spiritual, emosional dan intelektual.
\end{tabular}

\section{PENDAHULUAN}

Masa remaja merupakan masa peralihan, yaitu peralihan dari satu tahap perkembangan ke berikutnya. Artinya bahwa sesuatu yang terjadi pada tahap sebelumnya akan meninggalkan bekas pada tahap yang sedang dijalani dan tahap yang akan datang. Masa remaja adalah masa yang sangat menentukan karena masa ini anak-anak banyak mengalami perubahan psikis dan fisiknya. Terjadinya perubahan kejiwaan menimbulkan kebingungan dikalangan remaja, mereka mengalami gejolak emosi dan tekanan jiwa sehingga menyimpang dari aturan dan norma-norma sosial yang berlaku dikalangan masyarakat. ${ }^{1}$

Masa peralihan perkembangan dan pertumbuhan yang dihadapi oleh remaja akibat berbagai perubahan fisik, sosial, emosional yang semuanya itu menimbulkan rasa cemas dan ketidaknyamanan. Akibatnya masa ini disebut juga dengan masa yang penuh dengan badai dan tekanan, karena remaja harus belajar beradaptasi dan menerima semua perubahan yang seringkali menyebabkan pergolakan emosi di dalamnya. Menurut Ginanjar (2005) apabila aktivitas yang dijalani remaja bersama-sama dengan teman sebayanya tidak memadai untuk memenuhi tuntutan gejolak energinya, maka remaja seringkali meluapkan energinya ke arah yang negatif. Hal ini dapat terjadi karena lingkungan seringkali tidak sesuai dengan keinginan atau harapan batin, sehingga seseorang mengalami kekecewaan akibat ketidakseimbangan antara harapan dan kenyataan. ${ }^{2}$

\footnotetext{
${ }^{1}$ Gatot Marwoko, Psikologi Perkembangan Masa Remaja, jurnal pendidikan agama islam STAI Ihyaul Ulum Gresik, 60.

2 Khoirul Bariyyah dan M Farid, Konsep Diri, Adversity Quotient dan Penyesuaian Diri pada Remaja, jurnal fakultas fsikologi Universitas 17 Agustus 1945 Surabaya, Universitas Darul Ulum Jombang. Mei 2016, Vol. 5, No. 02, 138.
} 
Oleh sebab itu seorang remaja biasanya melakukan suatu hal tanpa dipikir panjang terlebih dahulu tentang akibat yang terjadi selanjutnya. Sehingga usaha untuk membentuk generasi penerus yang diharapkan sulit untuk diwujudkan. Seperti yang kita tahu bahwa remaja masa kini adalah pemimpin dimasa mendatang. Apabila generasi bobrok maka bobroklah calon pemimpin-pemimpin masa depan.

Seorang remaja haruslah memiliki spiritualitas yang kokoh, emosi yang terarah dan wawasan yang luas guna mempertahankan diri dari perilaku menyimpang. Remaja adalah generasi yang memiliki potensi, maka dari itu dibutuhkan sebuah wadah untuk menampung aspirasi sekaligus tempat aktualisasi diri.

Melihat fenomena yang terjadi saat ini, khususnya di lingkungan sekitar penulis, banyak sekali remaja yang berperilaku menyimpang akibat kurangnya pembinaan karakter dan spiritual pada remaja karena banyak diantara mereka yang sudah berhenti mengaji. Selain daripada itu, banyak juga remaja-remaja yang tidak produktif dan tidak berperan aktif di berbagai kegiatan sosial, kebanyakan dari mereka hanya menghabiskan waktu di rumah saja.

Maka dari itu perlu adanya wadah ataupun ruang bagi remaja untuk mendapat pembinaan agama, dan pelatihan-pelatihan yang dapat meningkatkan keterampilan mereka. Potensi serta energi yang ada dalam diri remaja harus digunakan untuk kebaikan dan kemaslahatan baik untuk diri remaja itu sendiri maupun lingkungan tempat mereka tinggal. Maka dari itu sebuah wadah atau program kajian milenial sangat perlu untuk menunjang para remaja agar dapat mengasah keterampilan, menggali potensi, mendapat pembinaan karakter keislaman serta tempat berbagai kegiatan produktif serta positif. Dengan adanya wadah berupa kajian milenial ini, pemberdayaan terhadap remaja diharapkan dapat meningkatkan kualitas sumber daya manusia khususnya remaja di Kampung Cigintung.

Banyak sekali kajian literatur yang membahas mengenai pentingnya perberdayaan remaja untuk kemajuan suatu bangsa. Seperti yang dikatakan oleh Pujangga Atmaja dan Amika Wardana, Ph.D, Mahasiswa Pendidikan Sosiologi Fakultas Ilmu Sosial Universitas Negeri Yogyakarta, penelitiannya berjudul "Peran Orema Al-Ikhlas Dalam Pemberdayaan Remaja Islam di Patukan", mengatakan bahwa masa remaja merupakan masa emas dalam kehidupan seseorang. Apabila masa remaja seseorang diberikan pengarahan yang baik maka, sangat bermanfaat terhadap potensi yang dimiliki. Kemajuan umat Islam di masa mendatang terletak pada kondisi dan kualitas generasi muda Islam masa kini.

Selain itu, menurut Pujangga Atmaja dan Amika Wadana, Ph.D, salah satu upaya pemberdayaan remaja yang efektif adalah membentuk sebuah lingkungan yang mampu memberikan kebaikan bagi remaja (islami). Lingkungan islami yang mampu mendukung image mereka secara positif dan menuntun mereka pada kepribadian yang benar. Lingkungan islami memberikan kemudahan dalam melakukan pembinaan terhadap remaja. Pembinaan remaja islami bertujuan agar remaja tersebut menjadi anak yang saleh; yaitu anak baik, beriman, berilmu, terampil dan berakhlak mulia.

Untuk membina remaja bisa dilakukan dengan berbagai metode, salah satunya melalui pendekatan Remaja Masjid. Remaja Masjid adalah organisasi atau wadah perkumpulan remaja yang menggunakan masjid sebagai pusat aktivitasnya. Remaja Masjid merupakan salah satu alternatif pembinaan remaja yang terbaik. Melalui wadah Remaja Masjid mereka memperoleh lingkungan yang islami serta dapat mengembangkan kreativitas.Selain dari pada itu, Arifiyani juga mengatakan dalam jurnalnya yang berjudul “Pengembangan Metode Dakwah Di Kalangan 
Remaja (Studi Pada Kumpulan Remaja Masjid At-Taqwa "Kurma" Di Kecamatan Boja Kabupaten Kendal"

Menurut Arifiyani, Remaja merupakan salah satu kalangan mad'u yang unik. Sifat unik ini bertolak dari karakteristik diri yang dimiliki oleh para remaja. Sebagai fase peralihan dari masa anak-anak menuju dewasa, pada fase remaja, umumnya terjadi usaha dalam pencarian jatidiri. (Nurpratiwi, 2021) Proses dakwah yang dilakukan kepada remaja akan berbeda dengan proses dakwah yang dilakukan kepada orang tua. Maka dari itu proses dakwah bagi remaja sangat penting dan vital.

Proses dakwah dapat menjadi media untuk mengontrol serta membentuk perilaku remaja yang diharapkan oleh dan sesuai dengan nilai-nilai ajaran Islam. Namun demikian, proses dakwah di kalangan remaja tidak dapat dilaksanakan secara asal-asalan. Dai harus memperhatikan karakteristik yang ada dalam diri remaja. Pemilihan metode dakwah di kalangan remaja masjid harus dilakukan dengan mempertimbangkan ciri remaja. Secara tidak langsung, metode dakwah yang digunakan harus tidak bertentangan dengan dampak perkembangan psikologi dan psikis remaja.

Dakwah untuk remaja dapat disandarkan pada salah satu hadits Nabi Muhammad SAW yang disampaikan oleh Abu Hurairah sebagai berikut:

Artinya: "Ada tujuh golongan manusia yang akan mendapat naungan Allah pada hari yang tidak ada naungan kecuali naungan-Nya: Pertama, Pemimpin yang adil, Kedua, Pemuda yang tumbuh di atas kebiasaan ibadah kepada Rabbnya, Ketiga, Lelaki yang hatinya terpaut dengan masjid, Keempat, Dua orang yang saling mencintai karena Allah, sehingga mereka tidak bertemu dan tidak juga berpisah kecuali karena Allah, Kelima, Lelaki yang diajak (berzina) oleh seorang wanita yang mempunyai kedudukan lagi cantik lalu dia berkata, „Aku takut kepada Allah, Keenam, Orang yang bersedekah dengan sembunyi-sembunyi, hingga tangan kirinya tidak mengetahui apa yang diinfakkan oleh tangan kanannya, Ketujuh, Orang yang berdzikir kepada Allah dalam keadaan sendiri hingga kedua matanya basah karena menangis." (HR. Al-Bukhari no. 620 dan Muslim no. 1712)

Hadits di atas secara jelas dapat menjadi penegas bahwa dakwah di kalangan remaja sangat penting untuk menjadikan remaja maupun pemuda sebagai generasi penerus yang terbiasa beribadah. Dalam hadits tersebut, tujuan dakwah adalah untuk memasukkan remaja ke dalam salah satu dari tujuh golongan yang masuk surga. Namun secara duniawi, dengan adanya dakwah menjadikan remaja sebagai generasi penerus bangsa dan syiar agama yang berkualitas.

\section{METODE}

Metode kegiatan ini menggunakan Participatory Research, di mana peneliti terlibat langsung dala proses pemberdayaan remaja di Desa Legok Huni Kecamatan Wanayasa, Purwakarta dengan menadakan kegiatan pengajian dan diskusi.

\section{HASIL DAN PEMBAHASAN}

\section{A. Hasil Kegiatan}

Remaja-remaja yang berada di wilayah kampung Cigintung Desa Legokhuni banyak diantaranya yang tidak produktif dan tidak memiliki kegiatan. Hal ini dapat dilihat dari ketidakterlibatan mereka dalam berbagai kegiatan seperti PHBI (Peringatan Hari Besar Islam), kegiatan sosial seperti bakti sosial di lingkungan masjid dan jalan, serta banyak juga diantara remaja yang sudah berhenti mengaji, sehingga keilmuan agama yang dimiliki 
sangat terbatas. Selain daripada itu waktu luang yang dimiliki remaja di tengah kondisi pandemi seperti sekarang membuat mereka diam tanpa kegiatan, sebagian diantara mereka memilih untuk di rumah saja, sebagian lagi memilih untuk menghabiskan waktu untuk bermain dan membuang waktu sia-sia.

Peneliti memilih remaja sebagai subjek penelitian yaitu remaja yang berusia sekitar14-20 tahun, berdasarkan pada upaya pemberdayaan dan peningkatan kualitas sumber daya manusia khususnya remaja yang ada di Kampung Cigintung. Remaja merupakan masa emas, yang dapat kita manfaatkan energi mereka yang besar dalam halhal yang bermanfaat dan kebaikan.

Remaja yang menjadi subjek penelitian bersifat umum, yaitu remaja yang masih Sekolah Menengah, tidak Melanjutkan Sekolah Menengah, melanjutkan kuliah dan yang tidak melanjutkan kuliah. ${ }^{3}$

Peneliti menemukan beberapa permasalah yang terjadi pada remaja yang berada di kampung Cigintung Desa Legokhuni diantaranya sebagai berikut:

1) Kurangnya peran aktif pemuda/I atau remaja dalam setiap aktivitas ataupun kegiatan yang diselenggarakan di wilayah Cigintung, misalnya penyelenggaraan PHBI (Peringatan Hari Besar Islam). Hal ini disebabkan tidak adanya sebuah instruksi yang mengikat dari sebuah wadah atau komunitas yang dapat memanajemen remaja.

2) Banyak remaja yang terjerat pergaulan tidak sehat, misalnya nongkrong tidak jelas, ada juga diantaranya yang hamil di luar nikah. Semua disebabkan karena kurangnya pemahaman dasar mengenai agama, yang menyebabkan mereka tumbuh tanpa prinsip hidup yang islami.

3) Banyak remaja yang menghabiskan waktu luang dengan hal yang tidak produktif. Hal ini disebabkan karena tidak adanya wadah atau komunitas remaja yang memicu semangat mereka untuk menggali potensi yang dimiliki.

4) Individualisme terjadi pada remaja di lingkungan peneliti, diantaranya banyak remaja yang satu wilayah namun seperti tidak saling mengenal. Penyebabnya adalah tidak pernah ada satu forum yang menyatukan mereka.

Itulah beberapa permasalah remaja yang ada di lingkungan peneliti. Selama ini belum pernah ataupun tidak ada upaya dalam menangani permasalahan remaja. Jika di suatu desa biasanya ada IRMA (Ikatan Remaja Mesjid), namun di wilayah peneliti khususnya Cigintung belum terbentuk IRMA.

\section{Gambar 1. Kajian Remaja Milenial}
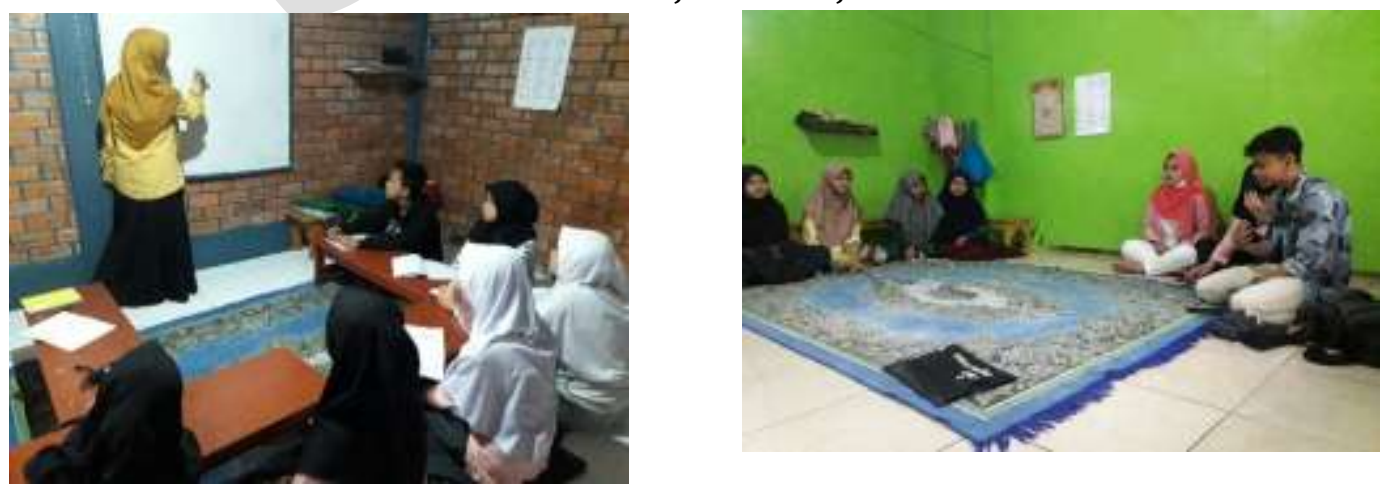

${ }^{3}$ Lampiran Arsip/ dokumen penting data remaja 
Gambar 2. KAMI Simulations

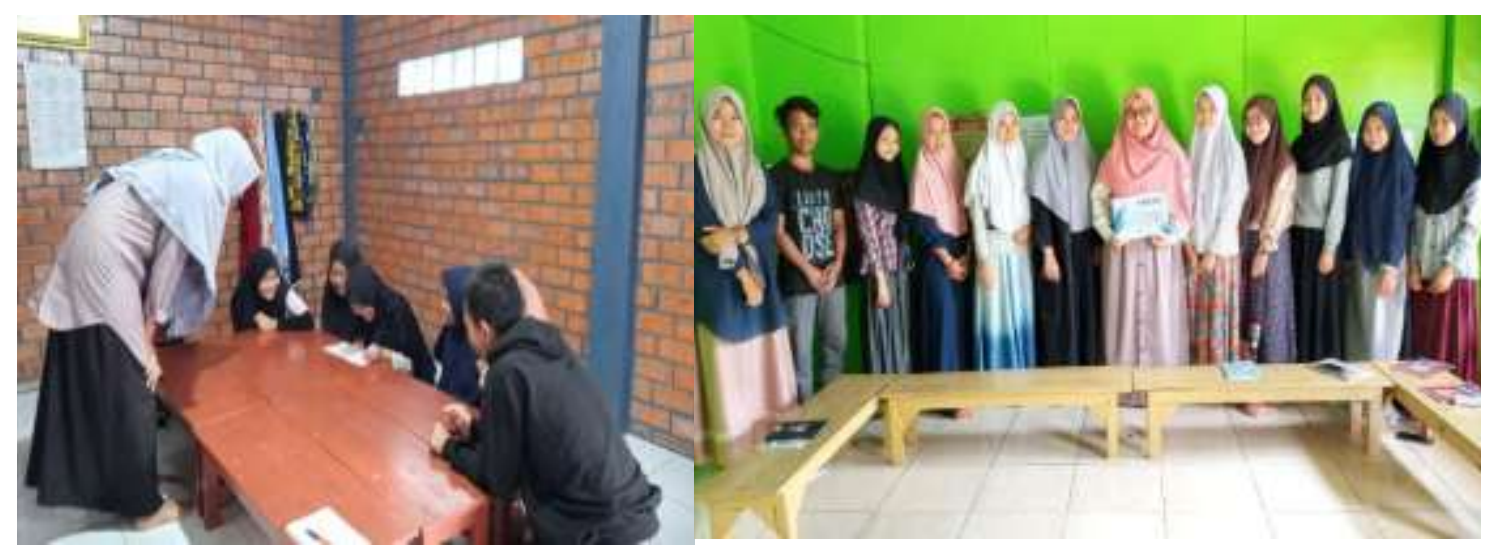

Gambar 3. KAMI Simulation

\section{B. Pembahasan}

Berdasarkan permasalahan mengenai remaja di wilayah kampung Cigintung, peneliti mencoba mencari upaya untuk mengatasi permasalah para remaja. Adapun upaya yang peneliti lakukan untuk permasalahan yang terjadi adalah dengan memberdayakan para remaja untuk menciptakan sumber daya manusia yang berkualitas baik secara spiritual, intelektual dan emosional dengan membentuk sebuah wadah berbentuk kajian agar memperkuat ukuwah diantara mereka. Kajian ini diisi dengan materi-materi keislaman dan materi umum untuk menggali dan melatih potensi yang mereka miliki sehingga nantinya diharapkan akan terbentuk sumber daya manusia khususnya remaja yang berkualitas baik secara spiritual, emosional maupun intelektual.

Upaya yang peneliti lakukan yaitu dengan membentuk sebuah komunitas atau program Kajian Milenial atau disingkat KAMI. Kajian ini dikhususkan bagi para remaja yang ada di wilayah kampung Cigintung. Dalam kajian ini, peneliti mencoba untuk mempersatukan remaja agar lebih kompak dan kreatif serta saling mengenal. Dibentuknya program ini tidak lain untuk mengajak remaja agar berperan aktif dalam berbagai kegiatan yang bermanfaat baik bagi diri sendiri ataupun orang lain.

Produk atau konsep baru yang peneliti hadirkan adalah program KAMI (Kajian Milenial) bagi para remaja di Kampung Cigintung Desa Legokhuni. Program ini bertujuan 
untuk meningkatkan kualitas sumber daya manusia dan sebagai bagian dari upaya pemberdayaan remaja.

Program KAMI (Kajian Milenial) merupakan program transformasi dari IRMA (Ikatan Remaja Mesjid). Atau dengan kata lain KAMI adalah program IRMA yang telah di upgrade atau diperbaharui.

Dalam program KAMI (Kajian Milenial) memiliki dua bentuk kajian yaitu diantaranya:

Pertama, Kajian Keagamaan. Dalam kajian keagamaan yang dibahas dan diperdalam adalah materi-materi tentang agama, misalnya fiqih, akidah akhlak, Al-Qur'an, tarikh dll. Dalam kajian keagamaan ini juga peneliti bekerjasama dengan ustad/ ustadzah muda yang ada di kampung Cigintung untuk kemudian mengisi kajian.

Kedua, Kajian Umum. Dalam kajian umum yang dibahas adalah materi-materi yang bersifat pengetahuan umum diantaranya public speaking (belajar MC, belajar presentasi dan diskusi), kesenian misalnya belajar hadroh, nasyid dll, pelibatan dalam PHBI (Peringatan Hari Besar Islam), menjadi relawan bakti sosial di lingkungan kampung Cigintung, serta menjadi panitia pesantren kilat setiap ramadhan. Adapun pemateri kajian umum ini diisi oleh peneliti sendiri serta mengundang orang-orang yang memang mumpuni dibidangnya, sistem yang dilakukan seperti sebuah seminar pada umumnya.

Selain daripada itu program KAMI juga mengadakan Khatam Qur'an Online, peneliti menggunakan istilah One Week One Juz (OWOJ), dimana setiap peserta diberi jatah satu juz yang harus diselesaikan dalam satu pekan. Program ini menggunakan WhatsApp Group sebagai sarana informasi mengenai pembagian juz dalam Al-Qur'an. Adapun tadarus dilakukan secara sendiri-sendiri di rumah masing-masing.

Masa remaja adalah masa transisi atau masa pencarian jati diri. Arahan dan bimbingan merupakan hal yang harus dilakukan pada remaja guna menghindari penyimpangan perilaku. Remaja membutuhkan suatu wadah atau ruang untuk mengembangkan potensi serta mengaktualisasikan diri.

Melihat fenomena yang terjadi pada remaja di lingkungan peneliti, misalnya kenakalan remaja, kurangnya kegiatan positif, tidak adanya peran aktif remaja, serta sifat individualis pada remaja menjadi motivasi bagi peneliti untuk membuat suatu program yang dapat merubah keadaan tersebut. Oleh karena itu peneliti membentuk sebuah program Kajian Milenial (KAMI).

Program Kajian Milenial (KAMI) ini bertujuan untuk meningkatkan kualitas sumber daya manusia khususnya remaja di wilayah kampung Cigintung baik secara spiritual, emosional dan intelektual.

\section{KESIMPULAN}

Masa remaja adalah masa transisi atau masa pencarian jati diri. Arahan dan bimbingan merupakan hal yang harus dilakukan pada remaja guna menghindari penyimpangan perilaku. Remaja membutuhkan suatu wadah atau ruang untuk mengembangkan potensi serta mengaktualisasikan diri.

Melihat fenomena yang terjadi pada remaja di lingkungan peneliti, misalnya kenakalan remaja, kurangnya kegiatan positif, tidak adanya peran aktif remaja, serta sifat individualis pada remaja menjadi motivasi bagi peneliti untuk membuat suatu program yang dapat 
SIVITAS, Vol. 1. No. 1 Januari 2021, 10 - 16

merubah keadaan tersebut. Oleh karena itu peneliti membentuk sebuah program Kajian Milenial (KAMI).

Program Kajian Milenial (KAMI) ini bertujuan untuk meningkatkan kualitas sumber daya manusia khususnya remaja di wilayah kampung Cigintung baik secara spiritual, emosional dan intelektual.

\section{DAFTAR PUSTAKA}

Arifiyani. (2015). Pengembangan Metode Dakwah Di Kalangan Remaja (Studi Pada Kumpulan Remaja Masjid At-Taqwa "Kurma" Di Kecamatan Boja Kabupaten Kendal, skripsi Fakultas Dakwah Dan Komunikasi Universitas Islam Negeri Walisongo, Semarang. Bariyyah, Khoirul dan M Farid. (2016). Konsep Diri, Adversity Quotiesnt dan Penyesuaian Diri pada Remaja. Jurnal Fakultas Fsikologi Universitas 17 agustus 1945, Surabaya.

Marwoko, Gatot. Psikologi Perkembangan Masa Remaja. Jurnal Pendidikan Agama Islam STAI Ihyaul Ulum Gresik.

Nurpratiwi, M. R. E. dan S. (2021). Hubungan Keberagamaan dan Perilaku Altruistik Mahasiswa. Al-Afkar, 4(1), 83-97.

https://doi.org/https://doi.org/10.31943/afkarjournal.v4i1.181

Effendi, M. R., \& Nurpratiwi, S. (2021). H Hubungan Keberagamaan dan Perilaku Altruistik Mahasiswa. al-Afkar, Journal For Islamic Studies, 4(1).

Pujangga Atmaja dan amika Wardana. (2016). Peran Oerma Al-Ikhlas dalam Pemberdayaan Remaja Islam di Patukan. Jurnal sosiologi fakultas ilmu sosial universitas negeri, Yogyakarta. 